\title{
Poaceae pollen in the air depending on the thermal conditions
}

\author{
Dorota Myszkowska
}

Received: 16 March 2013 /Revised: 9 May 2013 / Accepted: 10 May 2013 /Published online: 21 June 2013

(C) The Author(s) 2013. This article is published with open access at Springerlink.com

\begin{abstract}
The relationship between the meteorological elements, especially the thermal conditions and the Poaceae pollen appearance in the air, were analysed as a basis to construct a useful model predicting the grass season start. Poaceae pollen concentrations were monitored in 19912012 in Kraków using the volumetric method. Cumulative temperature and effective cumulative temperature significantly influenced the season start in this period. The strongest correlation was seen as the sum of mean daily temperature amplitudes from April 1 to April 14, with mean daily temperature $>15{ }^{\circ} \mathrm{C}$ and effective cumulative temperature $>3{ }^{\circ} \mathrm{C}$ during that period. The proposed model, based on multiple regression, explained $57 \%$ of variation of the Poaceae season starts in 1991-2010. When cumulative mean daily temperature increased by $10^{\circ} \mathrm{C}$, the season start was accelerated by 1 day. The input of the interaction between these two independent variables into the factor regression model caused the increase in goodness of model fitting. In 2011 the season started 5 days earlier in comparison with the predicted value, while in 2012 the season start was observed 2 days later compared to the predicted day. Depending on the value of mean daily temperature from March 18th to the 31st and the sum of mean daily temperature amplitudes from April 1st to the 14th, the grass pollen seasons were divided into five groups referring to the time of season start occurrence, whereby the early and moderate season starts were the most frequent in the studied period and they were especially related to mean daily temperature in the second half of March.
\end{abstract}

D. Myszkowska $(\bowtie)$

Department of Clinical and Environmental Allergology,

Jagiellonian University Medical College, Śniadeckich 10,

31-531 Kraków, Poland

e-mail: dmyszkow@cm-uj.krakow.pl
Keywords Poaceae pollen · Pollen season start . Temperature $\cdot$ Multiple and factor regression analyses . Kraków $\cdot$ Poland

\section{Introduction}

The plant pollen season appearance in the air is considered to be a biological indicator for estimation of the different plants behavior (Nilsson and Persson 1981; Bricchi et al. 1995; Norris-Hill 1998; Kasprzyk 2009), phenological phases (Menzel 2002; Huynen et al. 2003; Kasprzyk 2011) and climate changes (Frei and Leuschner 2000; Cariñanos et al. 2004). Aerobiological studies on the occurrence and dynamics of pollen seasons focus on the influence of different meteorological and anthropogenic factors on the pollen concentration, pollen season characteristics, and the pollen season forecast (Weryszko-Chmielewska 2007). It is also crucial information for people sensitive to pollen from view of diagnostics, therapy and prophylaxis of allergic rhinitis (Obtułowicz and Myszkowska 1995; Frenz 2001; Rapiejko 2000; Myszkowska 2007).

Poaceae pollen, as a dominant plant allergen in the western and central part of Europe (D'Amato et al. 2007), is especially important for botanical and medical analyses. The sources for clinical symptoms of allergic rhinitis provoked by plant pollen in Poland are successively: Poaceae, Betula, Artemisia, Corylus and Alnus (Samoliński et al. 2009). The study performed in Kraków showed that over $80 \%$ of patients with allergic rhinitis were sensitive to Poaceae pollen and the increase in allergy symptoms occurred from May to July with the peak period in the second half of June (Obtułowicz et al. 1991; Myszkowska et al. 2002).

The long Poaceae pollen season, as found by Szczepanek (1994), is determined by the number of species in flower (over 200 species in Poland) and their various pollination time. Frey (2007) reported that the following genera: 
Festuca (36 species), Bromus (26 species) and Poa (20 species) occur most numerously in Poland, while Avena (9 species), Agrostis, Phleum and Hordeum (9 species each) occur rarely. Dactylis sp. and Lolium perenne are often found (Zając and Zając 2001; Frey 2007). As a result of the management of the city verdure in Kraków natural meadows cover now up to $1 \%$ of the total acreage of the city.

Although many authors stress strong variability of pollen seasons in view of the pollen occurrence in the air and annual and intradiurnal differentiation of pollen concentrations (Emberlin et al. 1993; Chuine 2000; Yli-Panula et al. 2009), Poaceae pollen seasons show the relative timing of the appearance dates (Kasprzyk and Walanus 2010; Kasprzyk 2011). This refers especially to the start and end of the Poaceae pollen season (Myszkowska 2010, 2011). Low variability of the season start allows to forecast these characteristics in a consecutive year, although similarly as phenological phases, pollen seasons are periodical phenomena modified by weather conditions.

In the 1970s the first forecasts for Poaceae pollen season starts were published in London (Davies and Smith 1973), while the intensive increase in interest in modeling of processes of the pollen occurrence in the air started from the middle of the 1990s. Analysis of aerobiological literature indicates that the forecast model construction refers mainly to selected plant taxa, important from a medical, agricultural and phenological point of view. Other criterion used by researchers is variability of pollen season characteristics, which influence the choice of taxa of the low seasonal variability. These taxa are more useful for forecasting, for example, models for Poaceae pollen seasons (Schäppi et al. 1998; Burr 1999; Emberlin et al. 1999; Stach et al. 2008a; García-Mozo et al. 2009).

The answer as to which meteorological elements influence the Poaceae pollen season start is relatively complex. Results of analysis of dependence among these variables are not always comparable in different study centres (Dreissen et al. 1989, 1990; Emberlin et al. 1993; Smith et al. 2009; Kasprzyk and Walanus 2010). On the one hand it results from the employment of different methods defining pollen season characteristics and various methods of statistical analyses. On the other hand it results from the specific dependence of pollen seasons on weather conditions in a given area.

Thermal conditions occurring in different climatic regions influence the plant pollen seasons in given areas (Dahl et al. 2013). The basic temperature is estimated for anther splitting, plant readiness to flower opening, and anther extending. Many authors indicate the following meteorological elements related to the grass seasons start: mean temperature in March-April (Spieksma and Nikkels 1998), cumulative temperature above $5.5{ }^{\circ} \mathrm{C}$ in March-April
(Emberlin et al. 1993), mean temperature before the season start (Stach et al. 2008a), total rainfall in July (Ong et al. 1997) and minimum temperature in the first decade of April and maximum temperature in the second decade of April (Smith and Emberlin 2005).

The aim of this study, related to the previous results published in 2011 (Myszkowska), was to focus on different meteorological conditions just before the season, with special attention paid to the thermal conditions. The author intended to construct a useful model predicting the grass season start precisely and also explaining this phenomenon in a biological way.

\section{Materials and methods}

Aerobiological data were collected in Kraków (220 m a.s.l., $50^{\circ} 04^{\prime} \mathrm{N}, 19^{\circ} 58^{\prime} \mathrm{E}$ ) located in the Małopolska (Lesser Poland) province (Southern Poland) (Fig. 1). The city is surrounded by farmlands and forests. In the total acreage of the Małopolska province, arable lands cover $58.3 \%$, forest and forest grounds cover $29.1 \%$ and the remaining grounds (growing vegetables, ornamental and industrial plants) $12.6 \%$. Within the Kraków city, structures occupying an urban area are accompanied by the verdure (parks, squares, boulevards, botanical garden). The presence of particular natural communities (meadows) in the area of Kraków does not exceed $1 \%$ of surface except at rye Poaceae meadows (Arrhenatheretum elatioris tipicum) $(3.21 \%)$. A great part of the area is covered by fallow lands (Artemisietea) (13.28\%), followed by lawn and green belts (10.08\%) and thicket (4.68 \%) (Dubiel 2008). According to Zając and Zając (2006) the following grass species dominate in Kraków and the close vicinity of the city: Poa annua L., P. pratensis L., Festuca pratensis HUDS., F. rubra L. s. 1., Dactylis glomerata L., Arrhenatherum elatius (L.) P. BEAUV. Ex J. PRESL \& C. PRESL, Agrostis capillaris L., Elymus repens (L.) GOULD, and Phleum pretense L. s. 1., among them Arrhenatherum elatius, Elymus repens and some species belonging to Festuca spp. and Lolium spp. are reported as the species producing the majority of pollen (Pieto-Baena et al. 2003).

The main features of climate in Poland (including Kraków) are related to the general air masses of the polarmaritime origin coming from over the Northern Atlantic in this part of Europe. Mean annual air temperature in Kraków in the 20th century amounted to $8.7^{\circ} \mathrm{C}$, and 2000 was the hottest year $\left(11^{\circ} \mathrm{C}\right)$ (Piotrowicz 2007). The coldest month is January and the hottest is July (mean monthly temperatures $-2.1{ }^{\circ} \mathrm{C}$ and $18.9{ }^{\circ} \mathrm{C}$, respectively). Sunshine duration per day is $3.9 \mathrm{~h}$, although from April to September it is $5.7 \mathrm{~h}$ (Woś 1999). Mean annual precipitation is approximately $700 \mathrm{~mm}$. The highest rainfall level is recorded in summer 
Fig. 1 Study site location

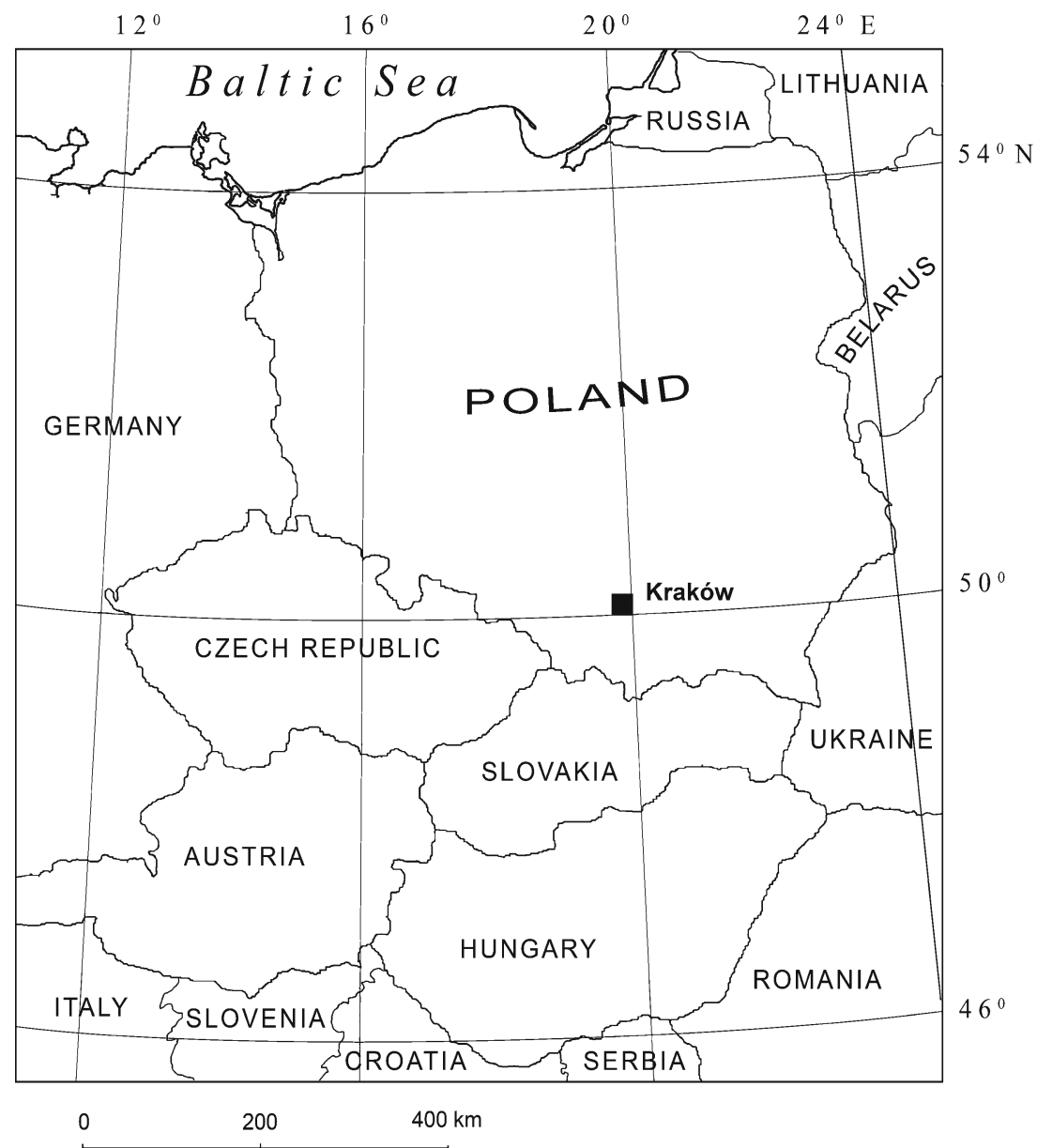

(June, July, August). In the annual cycle about $40 \%$ of rain falls in these months in Poland. Mean annual humidity is $79 \%$ and wind from westerly direction prevails. Mean wind velocity is relatively low, about $2.9 \mathrm{~ms}^{-1}$ (Woś 1999). The extension of Kraków, particularly from the second half of the 20th century (raising of Nowa Huta), undoubtedly caused the increase in air temperature inside the city in relation to outside areas. Intensity of the heat island in the city center is about $1.2{ }^{\circ} \mathrm{C}$ on average. In comparison with the 1950 s, winter is now shorter by 23 days in the centre of Kraków and summer is longer by 25 days (Lewińska 2000), which caused the extension of a vegetative season compared to the outside areas.

In the 20-year study period, mean air temperature was $9.1{ }^{\circ} \mathrm{C}$ and it was higher by $0.4^{\circ} \mathrm{C}$ than mean temperature in 1958-2010. This increase was caused, among other factors, by very warm summers $(2000,2007,2008)$ with mean annual temperature over $10^{\circ} \mathrm{C}$. The coolest year was 1996 (mean annual air temperature $7.1^{\circ} \mathrm{C}$ ). In the annual cycle the warmest month is usually July, and the coolest one is January. In the period under question, July was characterized by the highest temperature over 13 years (65\%). Temperature in winter months showed the highest variability, while in summer months it was the most stable. In the studied period spring was the hottest in 2000, 2001 and 2007 and it was relatively stable in the first years of observation. Summer was the most stable in 1996-2002 (Fig. 2). In the analyzed period, 1997 and 2010 were unique regarding precipitation. Intense precipitation in July 1997 and May 2010 was the reason for flooding.

Poaceae pollen concentrations have been monitored since 1991 using the Hirst type volumetric sampler, located on the roof top of the Collegium Śniadeckiego building, $20 \mathrm{~m}$ a. g. 1., in the center of the city. The pollen grains were counted in the microscopic slides along four longitudinal transects according to the method recommended by the European Aerobiology Society (Quality control) (Šikoparija et al. 2011). The pollen grains of a given genus or species were not distinguished, because of a distinct similarity in size, shape and sculpture. All identified grass pollen grains (excluding cereals) were presented as one taxon, i.e. the Poaceae family.

Meteorological data were delivered by the Research Station of the Dept. of Climatology, Institute of Geography and Spatial Management, Jagiellonian University $\left(50^{\circ} 04^{\prime} \mathrm{N}\right.$, $19^{\circ} 58^{\prime} \mathrm{E}, 206 \mathrm{~m}$ a.s.1.), which is located in the immediate vicinity of the monitoring site. To find the relationship between the pollen season start and meteorological data 
Fig. 2 Mean temperature in March, April, May, spring (March-May) and summer (June-August) in Kraków, in 1991-2010

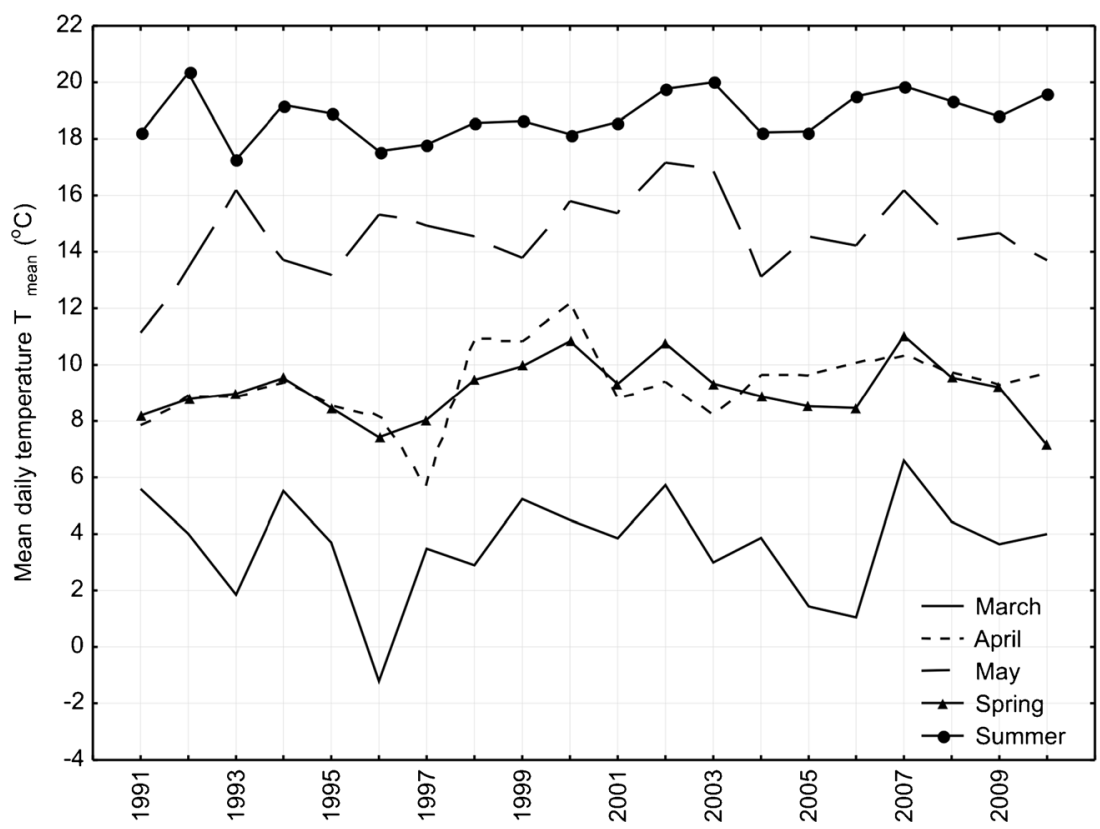

the following basic meteorological parameters were used: daily mean $\left(\mathrm{T}_{\text {mean }}\right)$, maximum $\left(\mathrm{T}_{\max }\right)$, minimum temperature $\left(\mathrm{T}_{\min }\right)$, relative humidity and relative sunshine, cloudiness, precipitation, snow cover. To find the relationship between Poaceae pollen season start and meteorological conditions before the season, the following meteorological data were calculated and considered:

- Cumulative temperature (sum of mean daily temperature, $\Sigma \mathrm{T}_{\text {mean }}$ ) calculated from the 1st of April to the season start in a given year (approximately 40 days before the average season start)

- Effective cumulative temperature (sum of mean daily temperature above the threshold value including $5-15^{\circ} \mathrm{C}$, considering values at intervals of $0.5{ }^{\circ} \mathrm{C}, \Sigma \mathrm{T}_{\text {mean }>5-15^{\circ} \mathrm{C}}$ ) calculated from the 1st of April to the season start in a given year

- The 14-day sum of meteorological data (mean daily temperature, precipitation, relative sunshine, relative humidity, cloudiness) calculated in the following periods: the second half of March (18-31 of March), first and second half of April (1-14 and 15-28 of April)

- The sum of daily temperature amplitudes $\left[\Sigma\left(T_{\max -} T_{\min }\right)\right]$ in the second half of March (18-31 of March), first and second half of April (1-14 and 15-28 of April)

- Precipitation in autumn and winter in the year preceding the year of observation (14-day periods in October and November, 1-14 of October, 15-28 of October, 29 of October-11 of November, $12-25$ of November)

Additionally the year of observation was taken into consideration as a factor probably influencing the season start in the following years.
The start of the Poaceae pollen season was defined using several methods, recommended by the European Aerobiology Society (www.ean.polleninfo.org; Stach and Kasprzyk 2005) and other authors, i.e. the percentage method (Emberlin et al. 1993; Nilsson and Persson 1981; Stach et al. 2008a), the cumulative sums method (Dreissen et al. 1989; AdamsGroom et al. 2002) and the threshold values method (Sánchez Mesa et al. 2003). In some papers the authors used different methods to compare the results precisely, e.g. Jato et al. (2009).

In relation to this point of view, the intention of the author was to show also the differences among the pollen season start dates calculated using these selected methods and to choose one of the cumulative methods closest to the $95 \%$ method. Using the percentage method, the date of the pollen season start was calculated employing $98 \%, 95 \%$, $90 \%$ methods, when $1 \%, 2.5 \%$ and $5 \%$ of the seasonal cumulative pollen count were trapped, respectively. However, these percentage methods could be applied when the season is over. The $95 \%$ method for the Poaceae pollen season start and the $90 \%$ method for the season end $(95 / 90 \%$ method) were indicated in the previous papers as the most efficient ones for the season start and end calculation in Kraków (Myszkowska 2010, 2011), because of the "cutting" of low concentrations mainly in the end of the post-peak period. The number of days without pollen before the peak day amounts to $6 \%$. The same situation after the peak amounts to $3 \%$. Applying the $95 / 90 \%$ method to the majority of days without pollen was excluded.

Focusing on the season start only, it seems to be more efficient to use the sum cumulative method, because the season start in the next year will be hard to predict using the percentage methods. It was a reason for the use of the 
following methods to calculate the Poaceae season start: pollen grain sum of $15,25,50,75$ cumulated since the 1 st of April, about 40 days before the mean season start in the studied period (1991-2010). Finally, the threshold methods of 20 and $50 \mathrm{PG} / \mathrm{m}^{3}$ were also considered.

The Spearman rank correlation test was used to find the relationship between season start and meteorological conditions. Constructing the predictive model, both variables (i) statistically significant correlated with the season start and (ii) non statistically significant correlated, but for which the correlation coefficients was higher than 0.4 , were considered. The multiple regression analysis was used to estimate the direction of the relationship between the season start and meteorological data. Non-correlated variables were taken into analysis and only those of a highest adjusted $\mathrm{R}^{2}$ value were considered as potential model parameters. Noncorrelated variables were used to avoid a co-linearity among independent variables. A two-variable model was determined, with the best fitting. Finally a model with explaining variables non-correlated between each other and explaining a great part of variability of the dependent variable was presented. In the Results section the functional form of the model and the value of an adjusted determination coefficient were pointed out. Models were constructed for data in 1991-2010 using the multiple regression analysis, which indicated factors responsible for the influence of meteorological elements on the pollen season start.

The variables well fitted in the model of multiple regression were then applied in the regression factor analysis to check the effect of the interaction among independent variables on the season start. Two-factor interaction was used in the model and a model best fitting the season start was presented. The models were constructed for data in 19912010 and validity was performed for data in 2011 and 2012 . To explain the influence of the meteorological variable on the season start better, the season starts calculated by the 15-sum method (c.f. Table 5) in 1991-2010 were divided into five groups: $<117$ (very early), 117-129 (early), 130-141 (moderate), 142-153 (late) and >153 $\left(\mathrm{PG} / \mathrm{m}^{3}\right)$ (very late). Analyses were carried out using the Statistica program version 9.0.

\section{Results}

The season start calculation

The beginning of the Poaceae pollen season defined using the threshold value method was reached the latest (approximately 143-159 day of a year). The threshold value of 20 $\mathrm{PG} / \mathrm{m}^{3}$ was reached in similar time as the daily pollen concentration reached in the start day defined using the $90 \%$ method (Table 1). The threshold value method of 50 $\mathrm{PG} / \mathrm{m}^{3}$ seems to be least useful, because it indicates the mean season start in the first decade of June. This value is too high for the season start in relation to daily concentration values reached during the season. The start date defined using the percentage methods is concurrent; the closest values are for the methods: $\Sigma 5,10,15$ pollen grains in relation to the methods: $\Sigma 25,50$ and 75 grains. The mean value of the season start day defined by the $90 \%$ method is similar to the threshold value method of 20 grains. Taking

Table 1 The descriptive statistics of the grass season start calculated using different methods in 1991-2010. The season start days in 2011 and 2012 are selected to verify the model

\begin{tabular}{|c|c|c|c|c|c|c|c|c|c|c|c|}
\hline \multirow[t]{2}{*}{ Season } & \multicolumn{11}{|c|}{ Method of the season start calculation } \\
\hline & $20^{\mathrm{a}}$ & $50^{\mathrm{a}}$ & $\Sigma 5^{\mathrm{b}}$ & $\Sigma 10^{\mathrm{b}}$ & $\Sigma 15^{\mathrm{b}}$ & $\Sigma 25^{\mathrm{b}}$ & $\Sigma 50^{\mathrm{b}}$ & $\Sigma 75^{\mathrm{b}}$ & $98 \%$ & $95 \%$ & $90 \%$ \\
\hline Min & 121.0 & 144.0 & 113.0 & 115.0 & 117.0 & 118.0 & 120.0 & 121.0 & 119 & 122 & 126 \\
\hline$Q_{1}$ & 132.0 & 154.5 & 121.5 & 122.5 & 122.5 & 123.0 & 129.0 & 134.0 & 125.5 & 130 & 139 \\
\hline$m e$ & 148.0 & 156.0 & 127.0 & 130.0 & 132.0 & 133.0 & 136.0 & 138.0 & 132.5 & 137.5 & 147 \\
\hline$Q_{3}$ & 154.0 & 166.0 & 133.0 & 134.5 & 137.0 & 141.5 & 146.5 & 148.5 & 137 & 145.5 & 153 \\
\hline $\max$ & 162.0 & 184.0 & 147.0 & 151.0 & 153.0 & 154.0 & 158.0 & 157.0 & 154 & 155 & 158 \\
\hline $\bar{x}$ & 143.1 & 159.8 & 127.7 & 129.7 & 131.3 & 133.3 & 137.4 & 139.7 & 132.45 & 137.8 & 145.6 \\
\hline$s$ & 12.3 & 11.3 & 8.8 & 9.0 & 9.5 & 10.4 & 11.6 & 10.4 & 8.95 & 9.85 & 8.77 \\
\hline$v \%$ & 8.6 & 7.1 & 6.9 & 7.0 & 7.2 & 7.8 & 8.4 & 7.4 & 6.76 & 7.15 & 6.02 \\
\hline $\begin{array}{l}{[-95 \%} \\
\quad+95 \%]\end{array}$ & $\begin{array}{r}137.3 ; \\
148.8\end{array}$ & $\begin{array}{l}154.5 \\
165.1\end{array}$ & $\begin{array}{r}123.5 \\
131.8\end{array}$ & $\begin{array}{c}125.4 \\
133.9\end{array}$ & $\begin{array}{l}126.7 \\
135.7\end{array}$ & $\begin{array}{r}128.3 ; \\
138.1\end{array}$ & $\begin{array}{r}131.9 \\
142.8\end{array}$ & $\begin{array}{r}134.7 \\
144.5\end{array}$ & $\begin{array}{c}128.26 \\
136.64\end{array}$ & $\begin{array}{c}133.19 \\
\quad 124.41\end{array}$ & $\begin{array}{l}141.5 ; \\
149.7\end{array}$ \\
\hline 2011 & 132 & 147 & 115 & 122 & 124 & 126 & 131 & 132 & 112 & 127 & 132 \\
\hline 2012 & 146 & 167 & 126 & 127 & 132 & 133 & 141 & 143 & 121 & 133 & 141 \\
\hline
\end{tabular}

a Threshold value $\left(\mathrm{PG} / \mathrm{m}^{3}\right)$

${ }^{\mathrm{b}}$ Cumulative pollen sum (day of the year) 
into consideration values of standard deviation, coefficient of variability and values of daily concentration in the first days of pollen appearance, the $\Sigma 15$ method was selected to analyze the relationship between the season start and the meteorological factors before the season.

\section{Correlation analysis}

The most significant relationships were found between meteorological variables and the season start in the first half of April (Table 2). Effective cumulative temperature and cumulative temperature significantly influenced the season start in this period only. The correlation coefficients ranged from 0.01 to 0.69 . The strongest correlation was pointed out in case of the sum of mean daily temperature amplitudes during April 1-14, with mean daily temperature $>15^{\circ} \mathrm{C}$, the consecutive year of observations and effective cumulative temperature $>3{ }^{\circ} \mathrm{C}$ in April 1-14.

The meteorological variables in the year preceding the year of observations (precipitation in autumn and winter) explained the low percentage of variation of dependent variable. In spite of relatively low values of the correlation coefficients, they were accepted as potential model variables. From a botanical and physiological point of view they were useful to explain the influence of meteorological elements on the season variation. Moreover, the significant trend to the earlier season start, related to the trend to the higher sum of temperature amplitudes was detected (Fig. 3).
The more distinct differences between $\mathrm{T}_{\max }$ and $\mathrm{T}_{\min }$ occurring in the first half of April, the earlier the grass season starts.

Multiple and factor regression analyses

The multiple regression model best fitted the data when including two independent variables: the sum of mean daily temperature amplitudes in April 1-14 and cumulative mean daily temperature in March 18-31. The cumulative mean daily temperature in March 18-31 was not considered as a significant variable using Spearman correlation analysis. The proposed model explained $57 \%$ of variation of the Poaceae season in 1991-2010 (Table 3). The estimation of the model parameters indicated that the sum of mean daily temperature amplitudes during 1-14 of April explained more variation of the season start (Table 3). When cumulative mean daily temperature increased by $10{ }^{\circ} \mathrm{C}$, the season start was accelerated by 1 day. On the other hand, when the sum of daily temperature amplitudes increased by $10^{\circ} \mathrm{C}$, the season started 3 days earlier.

Constructing the factor regression model, the interaction between two independent variables, $\mathrm{T}_{\text {mean }}$ in 18-31 of March and $\Sigma \mathrm{T}_{\max }-\mathrm{T}_{\min }$ in 1-14 of April, has been considered. This model explained $66 \%$ of variation of the season start. The estimation of the model parameters indicated that the sum of mean daily temperature amplitudes during the period 1-14 of April explained the higher percentage of the variability of the season start (Table 4). The input of the
Table 2 The selected Spearman's correlations between the Poaceae season start and meteorological parameters in Kraków in 1991-2010. Correlations are significant with $P<0.05$ level (2-tailed)

$N S$ non statistically significant

\begin{tabular}{ll}
\hline Independent variable & Correlation coefficient $r_{s}$ \\
\hline Study period: the second half of March & \\
Daily mean cumulative temperature $\Sigma \mathrm{T}_{\text {mean }}$ in $18-31$ of March & -0.39 (NS) \\
Mean relative sunshine in $18-31$ of March & -0.25 \\
Snow cover in $18-31$ of March & -0.02 \\
Study period: the first half of April & -0.63 \\
Daily mean cumulative temperature $\Sigma \mathrm{T}_{\text {mean }}$ in $1-14$ of April & -0.66 \\
Effective cumulative temperature $>3{ }^{\circ} \mathrm{C}$ in $1-14$ of April & -0.62 \\
Effective cumulative temperature $>5{ }^{\circ} \mathrm{C}$ in $1-14$ of April & -0.61 \\
Effective cumulative temperature $>6{ }^{\circ} \mathrm{C}$ in $1-14$ of April & -0.59 \\
Effective cumulative temperature $>7{ }^{\circ} \mathrm{C}$ in $1-14$ of April & 0.49 \\
Mean daily temperature below $0{ }^{\circ} \mathrm{C}$ in $1-14$ of April & \\
Study period: the second half of April & 0.52 \\
Mean daily temperature below $0{ }^{\circ} \mathrm{C}$ in $15-28$ of April & \\
Other variables & -0.65 \\
The consecutive year of observations & -0.19 \\
Precipitation in autumn in the year preceding the year of observations & -0.40 \\
Precipitation in winter in the year preceding the year of observations & -0.63 \\
Mean daily temperature $>15{ }^{\circ} \mathrm{C}(1-14$ of April) & -0.69 \\
The sum of mean daily temperature amplitudes in $1-14$ of April $\left(\Sigma \mathrm{T}_{\text {max }}-\mathrm{T}_{\text {min }}\right)$ & \\
&
\end{tabular}


Fig. 3 Scatterplots for the Poaceae pollen season start in 1991-2010 and the sum of daily temperature amplitudes from April 1st to the 14th

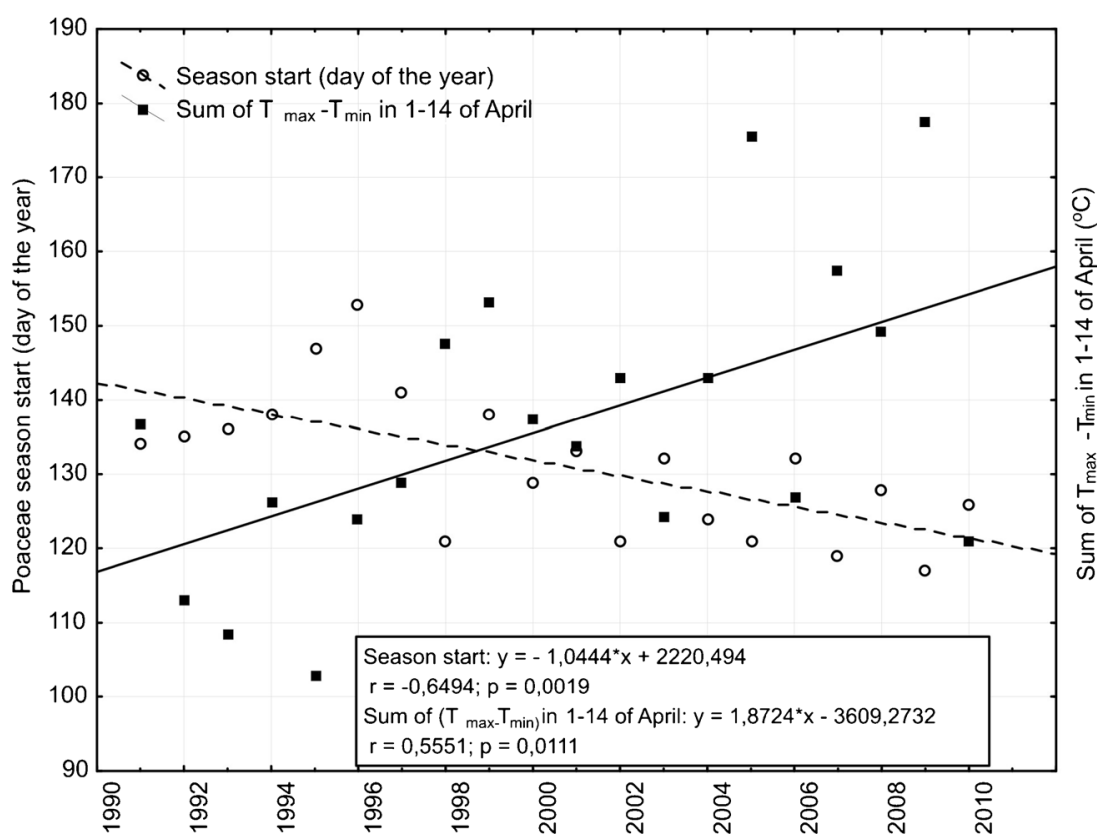

interaction between two independent variables caused the increase in goodness of model fitting.

In the studied period the very early season start was not indicated, early and moderate were found in 9 years, late in 1995 and 1996 only, and very late was not found (Fig. 4, Table 5). Considering the value of temperature just before the season start, the following relations were noted. Depending on the value of mean daily temperature in the second half of March and the sum of mean daily temperature amplitudes in the period of 1-14 of April, the type of the grass pollen season was determined. In case of the lowest cumulative daily mean temperature during the period 18-31 of March and the mean daily temperature amplitudes in 114 of April the predicted season start can be: very late, moderate and very early. In these weather conditions the daily temperature amplitudes in 1-14 of April influenced the grass season start strongly. When cumulative daily mean temperature in 18-31 of March was moderate and considering the different values of the mean daily temperature amplitudes in 1-14 of April, the season could start late, early and moderately. Otherwise, in case of high temperature in 18-31 of March, the season start was determined as early, early and moderate. Generally, if the sum of temperature amplitudes in 1-14 of April is high, the season started early (or moderate) regardless of the thermal conditions in 18-31 of March. The presented model well fitted the predicted season start dates, except in 1996, 1999, 2002 and 2007 (Fig. 5).

The factor regression model was validated using the data in 2011 and 2012. Both of these seasons were described as moderate start dates. In 2011 the season started 5 days earlier in comparison with the predicted value, while in 2012 the season start was observed 2 days later compared to the predicted day (Fig. 5).

\section{Discussion}

The grass pollen season observations performed in many European aerobiological centres indicate some tendencies in the season start. It is thought that they are affected by the unstable meteorological conditions. Herbaceous plants such as grasses present more immediate response to weather conditions than tree species (Dahl et al. 2013).

Cariñanos et al. (2004) pointed out that in the arid area of the Iberian Peninsula, where the grass pollen are detected through the whole year, peaking in May or June, rainfall in June prolongs flowering (resulting in the earlier season start). More intense flowering has also been observed in grass species if rainfall occurs in the 2-4-week period prior to flowering.

In the United Kingdom, research on variation in the grass season start performed at five stations (Emberlin et al. 1994) indicated cumulative mean daily temperature, cumulative temperature above $5.5^{\circ} \mathrm{C}$ and monthly precipitation from February to June as influencing the season start the strongest. Spieksma and Nikkels (1998) reported an evident trend to the earlier grass pollen season start date (6th of May, on average) on the basis of a 26-year observation in Leiden (the Netherlands). The authors found mean air temperature in the preceding period as a main factor influencing time of the season start. The best relations were noted between mean temperature from the 11th of April to the 20th of May and the season start, in cases when the season started on the 16th of May. The regression model built using these variables seemed to be very effective, as the season start was predicted within several days accuracy. The results of a 4-year observation carried out in Zagreb (Croatia) showed that the beginning of the Poaceae pollen season usually takes 


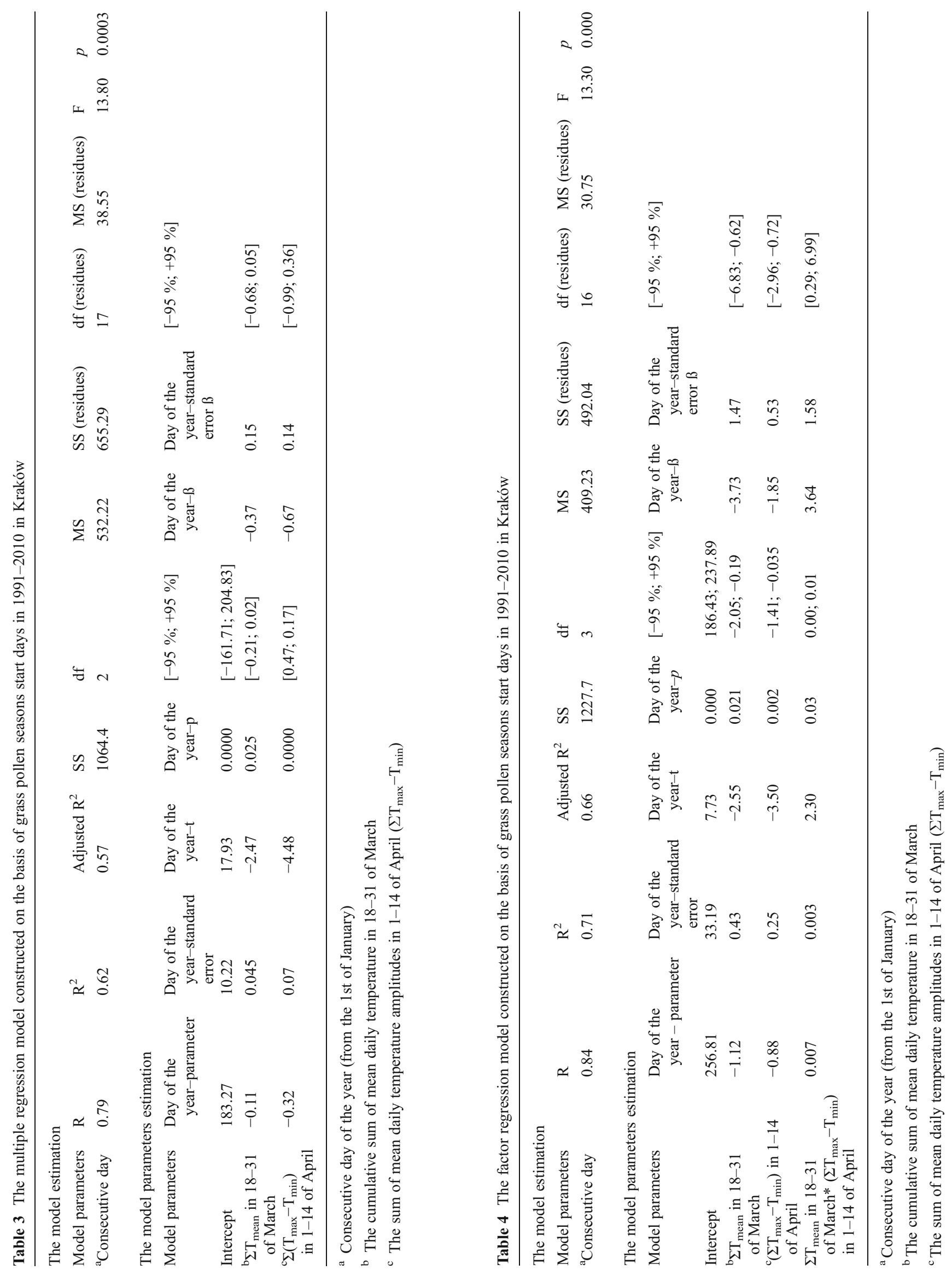


Fig. 4 The season start day calculated using the 15 -sum method ( $V E$ very early, $E$ early, $M$ moderate, $L$ late, $V L$ very late)

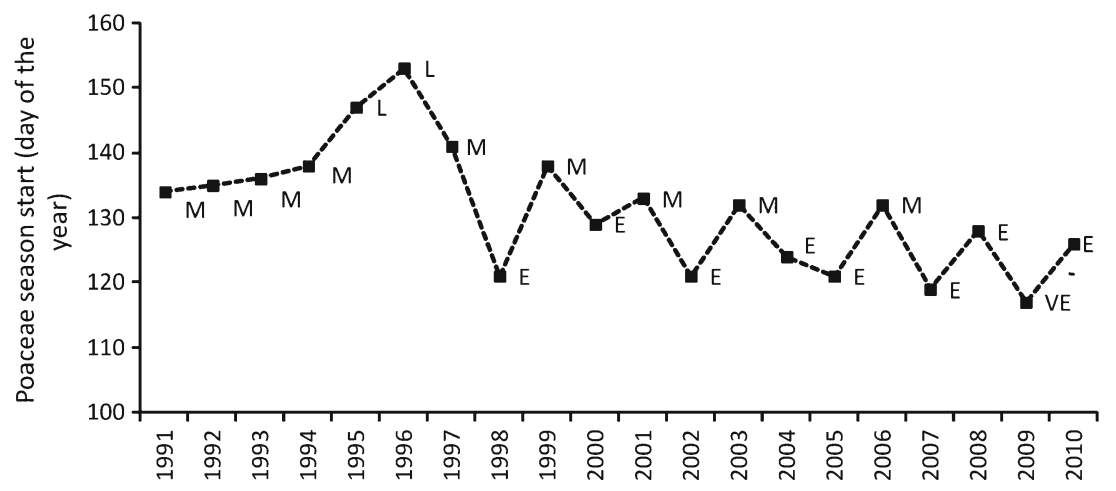

place when average daily temperature exceeds $13.5{ }^{\circ} \mathrm{C}$ (maximum daily temperature $19.5^{\circ} \mathrm{C}$, respectively), without precipitation. There was no clear trend because of a short time series used for analysis (Peternel et al. 2006).

In the previous paper on the relation between the grass pollen season start and meteorological conditions the season start was calculated using the percentage method (Myszkowska 2010). The regression models built on the basis of several data series (from 1991 to 2008) predicted the season start with the best accuracy when only one independent variable was introduced into a model (Myszkowska 2011). Mean temperature from the second decade of April influenced the start season the strongest. Precipitation in the first decade of May (121-130 days from the 1st of January) was also considered as a factor influencing the season start. The predicted dates differed from the observed ones by $0-9$ days in case of one variable models, while using the multivariable models the distinct differences were noted.

Because allergic symptoms are noted at the beginning of the pollen season, the reliable estimation of this moment and precise prediction are of great importance. In this paper the different methods of a season start calculation were presented, and finally the $\Sigma 5$ cumulative method was chosen as an optimal method associated with the pollen concentration thought to be potentially dangerous for the most sensitive patients, as indicated in the Polish Standards in Allergology (Samoliński et al. 2010). A similar method was applied by García-Mozo et al. (2009) in analyses focused on the grass pollen season starts and peak days in 12 sites in Spain.

The weather conditions in the second half of March influenced the season start in a significant way. Among many meteorological elements used in analysis, cumulative mean daily temperature was found to be a factor of the season start acceleration, in spite of a non significant correlation coefficient. However, this variable was introduced in the regression models. The result indicates that the weather conditions 1 month or more prior to the season start could influence the pollen occurrence. Such information was also reported by Emberlin et al. (1994) and Laadi (2001). Weather conditions in the first half of April rather than in the second half (just before the season start) affected the season beginning the strongest. A similar observation was reported

Table 5 The explanation of the predicted season start day regarding cumulative temperature in a given group of the season starts

\begin{tabular}{|c|c|c|c|}
\hline \multirow{2}{*}{$\begin{array}{l}\text { Variable } \\
\text { Cumulative daily mean temperature }\left(\mathrm{T}_{\text {mean }}\right) \text { in } 18-31 \text { of March }\left(\Sigma \mathrm{T}_{\text {mean }}\right)\end{array}$} & \multicolumn{3}{|c|}{ The lowest cumulative daily mean temperature in the studied period } \\
\hline & 9 & 9 & 9 \\
\hline The sum of mean daily temperature amplitudes in 1-14 of April $\left(\Sigma \mathrm{T}_{\max }-\mathrm{T}_{\min }\right)$ & 103 & 136 & 177 \\
\hline Predicted season start & 163 & 136 & 103 \\
\hline Type of the season & Very late & Moderate & Very early \\
\hline \multicolumn{4}{|l|}{ Moderate cumulative daily mean temperature in a studied period } \\
\hline Cumulative daily mean temperature $\left(\mathrm{T}_{\text {mean }}\right)$ in $18-31$ of March $\left(\Sigma \mathrm{T}_{\text {mean }}\right)$ & 74 & 74 & 74 \\
\hline 1The sum of mean daily temperature amplitudes in $1-14$ of April $\left(\Sigma \mathrm{T}_{\max }-\mathrm{T}_{\min }\right)$ & 103 & 136 & 177 \\
\hline Predicted season start & 142 & 131 & 119 \\
\hline Type of the season & Late & Moderate & Early \\
\hline \multicolumn{4}{|l|}{ The highest cumulative daily mean temperature in a studied period } \\
\hline Cumulative daily mean temperature $\left(\mathrm{T}_{\text {mean }}\right)$ in $18-31$ of March $\left(\Sigma \mathrm{T}_{\text {mean })}\right.$ & 139 & 139 & 139 \\
\hline The sum of mean daily temperature amplitudes in $1-14$ of April $\left(\Sigma \mathrm{T}_{\max }-\mathrm{T}_{\min }\right)$ & 103 & 136 & 177 \\
\hline Predicted season start & 120 & 127 & 135 \\
\hline Type of the season & Early & Early & Moderate \\
\hline
\end{tabular}


Fig. 5 Observed season start days vs predicted values in Kraków in 1991-2012. The values in 2011 and 2012 were marked with black circles as observed values and black squares as predicted values

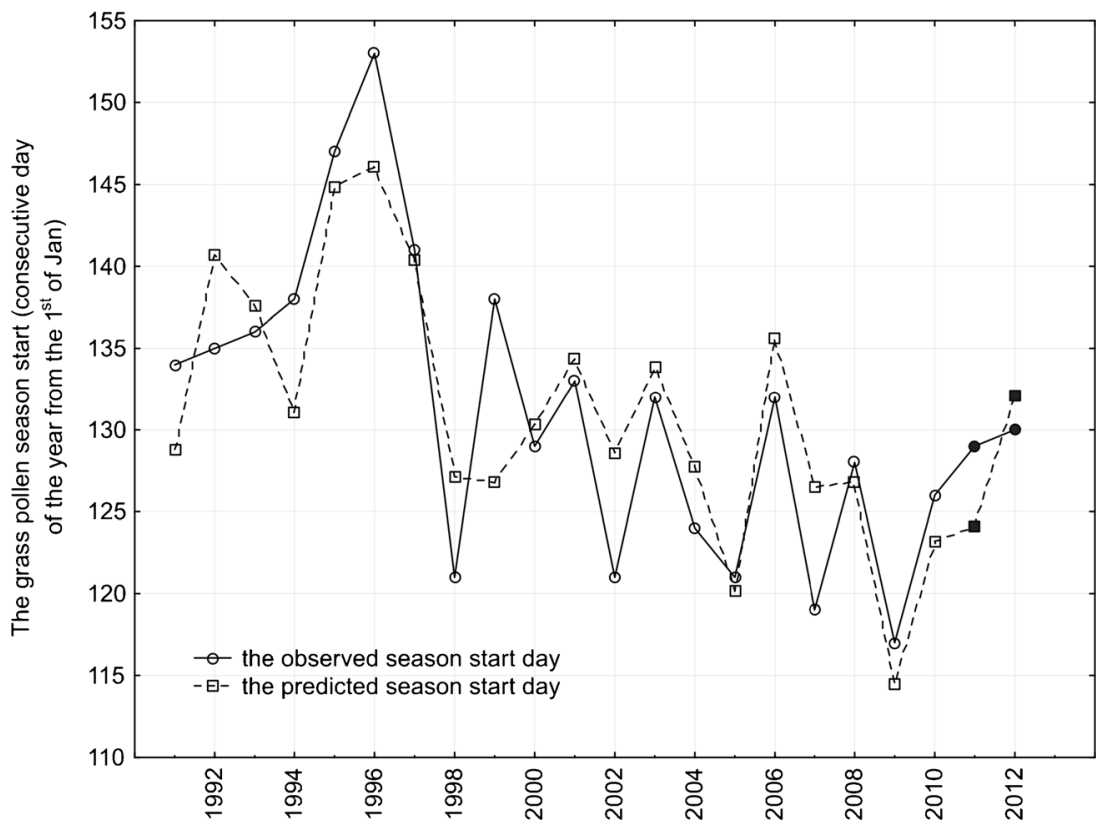

by Kasprzyk and Walanus (2010), who investigated the grass pollen seasons in Rzeszów (Southeastern Poland). They found temperature in the second and third decade of April as the best independent variable for forecasting the beginning of the main pollen season. They demonstrated three multiple regression models with one or two independent variables, but they showed a low percentage of variability. Laadi (2001) used maximum temperature during the 1st through 10th of April and rainfall from the 21st to the 30th of April as variables which correlated the best with the grass season onset to predict this characteristic using the multiple regression equation. These models reached $68 \%$ of prediction accuracy.

In the present study, daily mean temperature, cumulative daily temperature and the different cumulative effective temperature above the threshold values (ranges from 3 to $7^{\circ} \mathrm{C}$ ) should be treated as the factors impacting the grass pollen occurrence, although they were not included into the predictive models. These thermal conditions speed up the season start, similarly as cumulative daily mean temperature from the 18th to the 31 st of March included in the model. The method of summing temperature (cumulative summing the daily average temperature from a given date) was used also by Laadi (2001). He applied the wide range of thermal thresholds, above which daily temperature was effective from 0 to $9^{\circ}$ (increasing by $1^{\circ} \mathrm{C}$ ) testing the several dates from the 30th of January to the 10th of May. This method used for the season onset prediction gave quite good results, with a maximum inaccuracy of 4 days.

The occurrence of days with high mean daily temperature $\left(>15^{\circ} \mathrm{C}\right)$ in the second half of April in Kraków is also treated as a stress factor which could provoke the beginning of the season. During reproduction, a short period of heat stress could cause a significant increase in floral buds and flowers opening (Wahid et al. 2007). Daily temperature $>15{ }^{\circ} \mathrm{C}$ occurs in Kraków pretty rarely. During the $1991-$ 2010 period, mean monthly temperature did not reach this value, only in 5 years mean temperature in April ranged from 12.0 to $13.9{ }^{\circ} \mathrm{C}$ (Piotrowicz 2007).

The correlation analysis showed also the influence of temperature below $0{ }^{\circ} \mathrm{C}$ in April on the season start. The low temperature in the first and second half of April delayed the season start, but in the second half of April, just before the season, it is possible that low temperature, acting as a stress factor, could accelerate the grass season start. Some authors reported that the thermal conditions and water demand in the year preceding the year of observation could have influenced the grass season start. If in case of tree pollen seasons this impact is well documented (AdamsGroom et al. 2002; Latałowa et al. 2002; Stach et al. $2008 \mathrm{~b}$ ), there is a lack of information referring to the grass pollen seasons. In the present analysis, the distinct relationship between the weather in autumn and winter was found, apart from the low significant correlations with precipitation in Oct-Dec. It could be explained by the fact that the root system is superficial and therefore does not accumulate water.

Finally, the clear impact of the sum of mean daily temperature amplitudes from the 1st to the 14th of April $\left(\Sigma \mathrm{T}_{\max }-\mathrm{T}_{\min }\right)$ on the grass season start was confirmed. As was assumed, the temperature amplitudes are the greatest stress factors for plants speeding up the flowering. The present analysis showed also that these amplitudes increased in the course of years, which should be accepted as an indicator of the spring variety. In a studied period, the weak trend to higher maximum mean daily temperature during the 
1st through 14th of April was found. Probably, this is a reason for the more clear trend to higher cumulative amplitudes during the 1st through 14th of April.

To confirm and explain thoroughly the influence of the temperature amplitudes of April 1-14 on the grass pollen season start, factor regression analysis was performed. The model on the basis of the interaction between two independent variables: $\mathrm{T}_{\text {mean }}$ of March 18-31 and $\Sigma \mathrm{T}_{\max }-\mathrm{T}_{\min }$ of April 114 explained $66 \%$ of variation of the season start. Considering this interaction it was observed that different thermal situations in both time periods modified the type of the season start. In case of lowest cumulative daily mean temperature in the second half of March and: (i) the low mean daily temperature amplitudes of April 1-14 the season started very late, (ii) a moderate value, the season started moderately, (iii) a high value, the season started very early. This indicates that the cold March and rather stable thermal conditions in the first half of April (low amplitudes) slow down the season's start, which is opposite to the high amplitudes (less stable conditions), which speed up the season beginning. The impact of the cold and dry spring weather on grass season start was reported by Emberlin et al. (1999). Otherwise, when the temperature in March was relatively high the reverse phenomenon was met. In spite of days with the stable thermal conditions in the first half of April the seasons started early, while the days with high amplitudes (less stable conditions) did not speed up the season. Such observations were not reported earlier in aerobiological papers, but in the author opinion these results are really worthy of notice from a medical and biological point of view.

In 1992, 2002 and 2007 the predictive start day was delayed with regard to the observed day. In the cases of 2002 and 2007, these results could be explained by the highest temperature in March and spring in these years, but the observation in 1992 was not so evident. On the other hand, in 1994, 1996 and 1999 the seasons started before the predicted data, which could be associated with the lowest temperature in March in 1997. The model validation showed the small differences in the observed and predicted start days, 2 and 5 days respectively, in 2011 and 2012.

Concluding, regression analysis and especially factor regression analysis could be applied as a useful, nonsophisticated and relatively easy to interpret tool for the grass season start prediction. The presented relation between the season start and different combinations of thermal conditions of March 18-31 and April 1-14 explains well the variability of the season start.

Acknowledgements The study was supported by the grant of the Ministry of Science and Higher Education No. N305 021236 (20092011). The author would like to thank the management of the Department of Climatology, Jagiellonian University for providing me with the meteorological data and MSc Katarzyna Leśkiewicz from the Institute of Information and Library Science for her co-operation in statistical analysis.
Open Access This article is distributed under the terms of the Creative Commons Attribution License which permits any use, distribution, and reproduction in any medium, provided the original author(s) and the source are credited.

\section{References}

Adams-Groom B, Emberlin J, Corden J, Millington W, Mullins J (2002) Predicting the start of the birch pollen season at London, Derby and Cardiff, United Kingdom, using a multiple regression model, based on data from 1987 to 1997 . Aerobiologia 18:117123

Bricchi E, Frenguelli G, Mincigrucci G, Formaciari M, Ferranti F, Romano B (1995) Time linkages between pollination onsets of different taxa over 11-year period in Perugia, Central Italy. Aerobiologia 11:57-61

Burr ML (1999) Grass pollen: trends and predictions. Clin Exp Allergy 29:735-738

Cariñanos P, Galán C, Alcázar P, Domingues-Vilches E (2004) Airborne pollen records response to climatic conditions in arid areas of the Iberian Peninsula. Environ Exp Bot 52:11-22

Chuine I (2000) A united model for budburst of trees. J Theor Biol 2007:337-347

Dahl A, Galán C, Hajkova L, Pauling A, Sikoparija B, Smith M, Vokou D (2013) The onset, course and intensity of the pollen season. In: Sofiev M, Bergmann K-C (eds) Allergenic pollen. A review of the production, release, distribution and health impacts. Springer Science+Business Media, Dordrecht, pp 29-70

D’Amato D, Cecchi L, Bonini S, Nunes C, Annesi-Maesano I, Behrendt H, Liccardi G, Popov T, van Cauwenberge P (2007) Allergenic pollen and pollen allergy in Europe. Allergy 62:976-990

Davies RR, Smith LP (1973) Forecasting the start and severity of the hayfever season. Clinical Allergy 3:263-267

Dreissen MNBM, Van Herpen RMA, Moelands RPM, Spieksma FTM (1989) Prediction of the start of the grass pollen season for the western part of the Netherlands. Grana 28:37-44

Dreissen MNBM, Van Herpen RMA, Smithuis LOMJ (1990) Prediction of the start of the grass pollen season for the southern part of the Netherlands. Grana 29:79-86

Dubiel E (2008) Atlas roślinności rzeczywistej Krakowa. Urząd Miasta Krakowa, Kraków

Emberlin J, Savage M, Jones S (1993) Annual variations in grass pollen seasons in London 1961-1990: trends and forecast models. Clin Exp Allergy 23:911-918

Emberlin J, Jones S, Bailey J, Caulton E, Corden J, Dubbels S, Evans J, McDonagh N, Millington W, Mullins J, Russel R, Spencer T (1994) Variation in the start of the grass pollen season at selected sites in the United Kingdom 1987-1992. Grana 33:94-99

Emberlin J, Mullins J, Corden J, Jones S, Millington W, Brooke M, Savage M (1999) Regional variations in grass pollen seasons in the UK, long term trends and forecast models. Clin Exp Allergy 29:347-356

Frei T, Leuschner RM (2000) A change from grass pollen induced allergy to tree pollen induced allergy: 30 years of pollen observations in Switzerland. Aerobiologia 16:407-416

Frenz DA (2001) Interpreting atmospheric pollen counts for use in clinical allergy: allergic symptomology. Ann Allerg Asthma Im $86: 150-158$

Frey L (2007) Taksonomia traw. In: Frey L (ed) Biologia traw. Instytut Botaniki im. W. Szafera Polska Akademia Nauk, Kraków, pp 39-63

García-Mozo H, Galan C, Belmonte J, Bermejo D, Candau P, Díaz de la Guardia C, Elvira B, Gutíerrez M, Jato V, Silva I, Trigo MM, Valencia R, Chuine I (2009) Predicting the start and peak dates of the Poaceae pollen season in Spain using process-based models. Agr Forest Meteorol 149:256-262 
Huynen M, Menne B, Behrendt H, Bertollini R, Bonini S, Brandao R, Brown-Fährlander C, Clot B, D'Ambrosio C, de Nuntiis P, Ebi $\mathrm{KL}$, Emberlin J, Orbanne EE, Galan C, Jäger S, Kovats S, Mandrioli P, Martens P, Menzel A, Nyenzi B, Rantio-Lehtimäki A, Ring J, Rybnicek O, Traidl-Hoffman R, van Vliet A, Voigt T, Weiland S, Wickman M (2003) Phenology and human health: allergic disorders. Report of a WHO meeting, Rome

Jato V, Rodríguez-Rajo FJ, Saijo MC, Aira M (2009) Poaceae pollen in Galicia (N.W. Spain): characterization and recent trends in atmospheric pollen season. Int J Biometeorol 53:333-344

Kasprzyk I (2009) Forecasting the start of Quercus pollen season using several methods - the evaluation of their efficiency. Int $\mathrm{J}$ Biometeorol 53:345-353

Kasprzyk I (2011) Time series analysis of pollen seasons in Rzeszów (SE Poland) in 1997-2005 with reference to phenology. Habilitation thesis. Wydawnictwo Uniwersytetu Rzeszowskiego, Rzeszów

Kasprzyk I, Walanus A (2010) Description of the main Poaceae pollen season using Bi-Gaussian curves, and forecasting methods for the start and peak dates for this type of season in Rzeszów and Ostrowiec Sw. (SE Poland). J Environ Monit 12:906-916

Laadi M (2001) Forecasting the start of the pollen season of Poaceae: evaluation of some methods based on meteorological factors. Int $\mathrm{J}$ Biometeorol 45:1-7

Latałowa M, Miętus M, Uruska A (2002) Seasonal variations in the atmospheric Betula pollen count in Gdańsk (southern Baltic coast) in relation to meteorological parameters. Aerobiologiac 18:33-43

Lewińska J (2000) Klimat miasta. Zasoby, zagrożenia, kształtowani. Instytut Gospodarki Przestrzennej i Komunalnej: Oddział w Krakowie.

Menzel A (2002) Phenology: its importance to the global change community. Climate Change 54:379-385

Myszkowska D, Stępalska D, Obtułowicz K, Porębski G (2002) The relationship between airborne pollen and fungal spore concentrations and seasonal pollen allergy symptoms. Aerobiologia 18:153-161

Myszkowska D (2007) Zastosowanie badań aerobiologicznych w medycynie. In: Weryszko-Chmielewska E (ed) Aerobiologia. Wydawnictwo Akademii Rolniczej, Lublin, pp 85-94

Myszkowska D (2010) The grass pollen season dynamics in relation to the meteorological conditions in Kraków, Southern Poland, 19912008. Acta Agrobot 63:85-96

Myszkowska D (2011) Prognozowanie parametrów sezonu pyłkowego traw w Krakowie. Fragm Flor Geobot Polonica 18:397-407

Nilsson S, Persson S (1981) Tree pollen spectra in the Stockholm region (Sweden), 1973-1980. Grana 20:179-182

Norris-Hill J (1998) A method to forecast the start of the Betula, Platanus and Quercus pollen seasons in North London. Aerobiologia 14:165-170

Obtułowicz K, Myszkowska D (1995) Alergia pyłkowa. Wytwórnia Surowic i Szczepionek BIOMED w. Krakowie, Kraków

Obtułowicz K, Szczepanek K, Radwan J, Grzywacz M, Adamus K, Szczeklik A (1991) Correlation between airborne pollen incidence, skin prick tests and serum immunoglobulin in allergic people in Kraków, Poland. Grana 30:136-141

Ong EK, Taylor PE, Knox RB (1997) Forecasting the onset of the grass pollen season in Melbourne (Australia). Aerobiologia 13:43-48

Peternel R, Srnec L, Čulig J, Hrga I, Hercog P (2006) Poaceae pollen in the atmosphere of Zagreb (Croatia), 2002-2005. Grana 45:130 136

Piotrowicz K (2007) Temperatura powietrza. In: Matuszko D (ed) Klimat Krakowa w XX wieku. Instytut Geografii i Gospodarki Przestrzennej Uniwersytetu Jagiellońskiego, Kraków, pp 99 112
Pieto-Baena JC, Hidalgo PJ, Dominguez E, Galan C (2003) Pollen production in the Poaceae family. Grana 42:153-160

Rapiejko P (2000) Znaczenie pomiaru stężeń pyłku roślin dla oceny skuteczności pyłkowicy. Alergia Astma Immunologia 5:40-42

Samoliński B, Sybilski AJ, Raciborski F, Tomaszewska A, SamelKowalik P, Walkiewicz A, Lusawa A, Borowicz J, GutowskaŚlesik J, Trzpil L, Marszałkowska J, Jakubik N, Krzych E, Komorowski J, Lipiec A, Gotlib T, Samolińska-Zawisza U, Hała Z (2009) Prevalence of rhinitis in Polish population according to the ECAP (Epidemiology of Allergic Disorders in Poland) study. Otolaryngol Polska 63:324-330

Samoliński B, Rapiejko P, Lipiec A, Kurzawa R (2010) Metody ograniczania narażenia na alergen. In: Kruszewski J, Kowalski ML (eds) Standardy w alergologii. Część I. Medycyna Praktyczna, Kraków, pp 143-149

Sánchez Mesa JA, Smith M, Emberlin J, Allitt U, Caulton E, Galan C (2003) Characteristics of grass pollen seasons in areas of southern Spain and the United Kingdom. Aerobiologia 19:243-250

Schäppi GF, Taylor PE, Kenrick J, Staff IA, Suphioglu C (1998) Predicting the grass pollen count from meteorological data with regard to estimating the severity of hayfever symptoms in Melbourne (Australia). Aerobiologia 14:29-37

Šikoparija B, Pejak-Šikoparija T, Radišic P, Smith M, Galán Soldevilla C (2011) The effect of changes to the method of estimating the pollen count from aerobiological samples. J Environ Monit 13:384-390

Smith M, Emberlin J (2005) Constructing a 7-dayahead forecast model for grass pollen at north London, United Kingdom. Clin Exp Allergy 35:1400-1406

Smith M, Emberlin J, Stach A, Rantio-Lehtimäki A, Caulton E, Thibaudon M, Sindt C, Jäger S, Gehrig R, Frenguelli G, Jato V, Rodríguez-Rajo FJ, Alcázar P, Galán C (2009) Influence of the North Atlantic Oscillation on grass pollen counts in Europe. Aerobiologia 25:321-332

Spieksma FTM, Nikkels H (1998) Airborne grass pollen in Leiden, the Netherlands: Annual variations and trends in quantities and season starts over 26 years. Aerobiologia 14:347-358

Stach A, Kasprzyk I (2005) Metodyka badań zawartości pyłku roślin i zarodników grzybów w powietrzu z zastosowaniem aparatu Hirsta. Bogucki Wydawnictwo Naukowe, Poznań, pp 13-15

Stach A, Smith M, Prieto Buena JC, Emberlin J (2008a) Long-term and short-term forecast models for Poaceae (grass) pollen in Poznań, Poland, constructed using regression analysis. Environ Exp Botany $62: 323-332$

Stach A, Emberlin J, Adams-Groom B, Smith M, Myszkowska D (2008b) Factors that determine the severity of Betula spp. pollen seasons in Poland (Poznań and Kraków) and the United Kingdom (Worcester and London). Int J Biometeorol 52:311-321

Szczepanek K (1994) Pollen calendar for Kraków (southern Poland), 1982-1991. Aerobiologia 10:65-70

Wahid A, Gelani S, Ashraf M, Foolad MR (2007) Heat tolerance in plants: An overview. Environ Exp Bot 61:199-223

Weryszko-Chmielewska E (2007) Zakres badań i znaczenie aerobiologii. In: Weryszko-Chmielewska E (ed) Aerobiologia. Wydawnictwo Akademii Rolniczej, Lublin, pp 6-10

Woś A (1999) Klimat Polski. Państwowe Wydawnictwa Naukowe PWN, Warszawa

Yli-Panula E, Fekedulegn DB, Green BJ, Ranta H (2009) Analysis of airborne Betula pollen in Finland: A 31-year perspective. Int $\mathrm{J}$ Environ Res Public Health 6:1706-1723

Zając A, Zając M (eds) (2001) Distribution atlas of vascular plants in Poland. Laboratory of Computer Chorology, Institute of Botany, Jagiellonian University and Foundation of Jagiellonian University, Kraków 